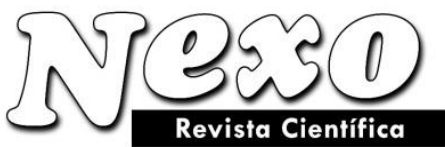

Vol. 33, No. 02, pp. 340-356/Diciembre 2020

\title{
Petrographic and isotopic studies in Kamoo area, northeast isfahan, Iran
}

\section{Estudios petrográficos e esotópicos en el área de Kamoo, Noreste de Isfahan, Irán}

\author{
Manouchehr Alahbakhshi ${ }^{1}$, Reza Mehrnia ${ }^{* 2}$, Mohammad Reza Espahbod ${ }^{3}$, Afshin Ashja-
} Ardalan ${ }^{4}$

1 Department of geology, North Tehran Branch, Islamic Azad University, Tehran, Iran. CP: 44531-67779, Tel.: (+98) 9113363219 - ma1057974@ gmail.com, http://orcid.org/ 00000002-2870-4910

2 Department of Geology, Payam Noor University, Iran. CP: 16746-88317, Tel.: (+98)

9122574607 - *Corresponding author: srmehrnia@yahoo.com, http://orcid.org/ 0000-00019801-4707

3 Department of geology, North Tehran Branch, Islamic Azad University, Tehran, Iran. CP: 14558-34935, Tel.: (+98) 9128437941-dr.espahbod@ gmail.com, http://orcid.org/ 00000002-0000-9326

4 Department of Geology, Islamic Azad University, North Tehran Branch, Tehran, Iran. CP: 165115-3311. Tel: (+98) 9122251562- afshinashjaardalan@yahoo.com, http://orcid.org/ 0000-0002-1800-9594

(recibido/received: 05-May-2020; aceptado/accepted: 15-July-200)

\begin{abstract}
The study area is located $5.5 \mathrm{~km}$ north-east of Kamo County and $30 \mathrm{~km}$ north-east of Meymeh, Isfahan. Kamo Index comprises an anticline with a northwest-southeast trend, the outcrop of which consists of siltstone-sandstone and Jurassic shale rocks that lie along a cretaceous unit. Based on field studies as well as petrographic and geochemical investigations, mineral assemblages and minerals in the area include chalcopyrite, pyrite, marcasite, and magnetite as primary ores and malachite, bornite, covellite, chalcocite, hematite, goethite, and hydrous iron oxides as secondary ores. The secondary ores have been formed by oxidation and biogenic processes. The primary textures are granular, disseminated, vein-shaped, and layered and the secondary textures are boxed and martitized, shear zones, replacements, and veins. Tectonic, metamorphic, and oxidation factors are involved in the formation of these textures. Due to tectonic activity in this area and the presence of faults, replacement, vein, and shear textures, which have developed after mineralization, are observed. Among alterations, hematite, propylitic, sericitic, limonitic, and kaolinitic are highly prevalent and they are important in the formation of
\end{abstract}


iron deposits. The sub-alkaline granitoids of the region are related to the continental subductionzone orogenic series. Studies on the decomposed iron samples from Kamo show that most of the samples are in the sub-alkaline series and the chemical and mineralogical composition of the magma derived from this series is calc-alkaline with a large amount of iron. According to mineralogical, lithological, and geochemical evidence and based on isotopic results, Kamo deposit is a skarn-type deposit.

Keywords: Isfahan, Kamoo, Mineralogy, Alteration, Skarn

\section{RESUMEN}

El área de estudio está ubicada a $5.5 \mathrm{~km}$ al noreste del condado de Kamo y a $30 \mathrm{~km}$ al noreste de Meymeh, Isfahan. El índice de Kamo comprende un anticlinal con una tendencia noroestesureste, cuyo afloramiento consiste en arenisca-arenisca y rocas de esquisto jurásico que se encuentran a lo largo de una unidad cretácea. Con base en estudios de campo, así como en investigaciones petrográficas y geoquímicas, los ensambles minerales y minerales en el área incluyen calcopirita, pirita, marcasita y magnetita como minerales primarios y malaquita, bornita, covenita, calcocita, hematita, goetita y óxidos de hierro hidratados como secundarios. Minerales Los minerales secundarios se han formado por oxidación y procesos biogénicos. Las texturas primarias son granulares, diseminadas, en forma de vena y en capas, y las texturas secundarias son en caja y martitizadas, zonas de cizallamiento, reemplazos y vetas. Los factores tectónicos, metamórficos y de oxidación están involucrados en la formación de estas texturas. Debido a la actividad tectónica en esta área y la presencia de fallas, se observan texturas de reemplazo, vetas y corte, que se han desarrollado después de la mineralización. Entre las alteraciones, hematita, propilítico, sericítico, limonítico y caolinítico son altamente prevalentes y son importantes en la formación de depósitos de hierro. Los granitoides subalcalinos de la región están relacionados con la serie orogénica continental de la zona de subducción. Los estudios sobre las muestras de hierro descompuesto de Kamo muestran que la mayoría de las muestras se encuentran en la serie subalcalina y la composición química y mineralógica del magma derivada de esta serie es alcalina con una gran cantidad de hierro. De acuerdo con la evidencia mineralógica, litológica y geoquímica y con base en los resultados isotópicos, el depósito de Kamo es un depósito tipo skarn.

Palabras clave: Isfahan, Kamoo, Mineralogía, Alteración, Skarn.

\section{INTRODUCCIÓN}

Around the world, convergent and collision boundaries between two plates create orogenic events. These boundaries contain a wide range of magmatic rocks and many types of associated mineral deposits (Richards 2009). Mineralization and ore deposit formation in orogenic belts are usually facilitated by hydrothermal alteration activities. Globally, most of the copper porphyry resources are located in orogenic belts and volcanic arcs (John et al. 2010). The Alpine-Himalayan Belt (Tethys) is one of the best examples of an orogenic system with high potential for magmatic-hydrothermal mineral resources including copper, molybdenum, gold, and epithermal silver (Hou and Cook 2009). A wide range of deposits from chromite ( \pm 3 elements in the platinum group) to copper \pm gold \pm molybdenum porphyry, meso-sulfide, and polymetallic deposits as well as active mineral resource formation processes are associated with the evolution of the tectonic magmatic rocks in the Iranian Neotethys belt (Daliran and Pirajno 2014, Nazemi et al, 2019, Yazdi et al, 2019). Copper \pm molybdenum \pm porphyry \pm gold and its dependent epithermal 
gold \pm copper sources dominate this belt (Richards 2015, Baratian et al. 2020). The occurrence of ore mineralization in each geological setting depends on various factors, namely the existence a source of metallic elements (different lithological units present in the path of fluid and magma), the presence of a fluid to transport metals and their carrier complexes (hydrothermal fluid, magma), and a suitable geological environment for deposition and ore formation. Different geological environments have become sites for various types of ore deposits due to events that have occurred during the geologic time. The study area is located $5.5 \mathrm{~km}$ northeast of Kamo County and $30 \mathrm{~km}$ northeast of Meymeh, Isfahan. In this area, studies have been carried out using different exploration methods, e.g., geochemical and geophysical, and drilling. In this research, new data (XRD, isotopic) will be provided also we investigate the petrography and mineralogy of ores and alteration zones. The aim of this present study is to obtain geochemical properties of granitoids, determining magmatic series and according to geochemical findings determining deposit type.

\section{METHODOLOGY}

For preliminary geochemical investigations in Kamo area, sampling of rock units or outcrops was done using clustering as well as lobster and groove sampling and coordinates of the sampling sites were recorded using GPS. Sedimentary outcropping; intrusive bodies; skarn, metallic, and non-metallic minerals; and zones of alteration were sampled. Samples were analyzed with respect to mineralization, structural geology, and lithological changes. After the initial counting and preparation, samples were taken to Igneous Zinc Laboratory for XRD analysis. Samples were also sent to Binalood Ore Mining Company for XRF analysis. Microscopic study of polished sections and polished thin sections was performed by Olympus "Model BX51" using refractive and reflective properties. Since the largest volume of sulfide minerals in the region was composed of pyrite minerals, 6 samples of pyrite sulfide minerals were taken from the deposit to investigate the isotopic composition of sulfur. The samples were sent to the "G.G. Hatch Isotope Laboratory" in Canada after initial preparation, including separation and purification. To investigate different alteration units in the study area during field survey, alteration control in different rocks was investigated.

\section{GEOLOGY OF THE STUDY AREA}

According to the geological map of Kashan, there are rock units from three geological periods (Paleozoic, Mesozoic, and Cenozoic) in the study area. In terms of structure, the Kamo Index includes a northwestsoutheast anticline with the outcrop section consisting of siltstone-sandstone and Jurassic shale rocks. However, this section has not fully outcropped and only its upper sections have been exposed to erosion, on which the Cretaceous unit has formed, creating an unconformity (Bagheri 1998). Borna and Janessari introduced the core of this anticline as the site of intrusions of granodiorite and dacite-andesite compositions (Borna and Janessary 1993). The main trend of these dykes is parallel to the main Ab-Sard Valley fault along the northeast-southwest direction, almost perpendicular to the geological structures in th Urmiyeh-Dokhtar zone and the anticline Expansion of skarn on both sides of the main Ab-Sard valley fault and extension of alteration zones along this fault indicate that this fault and its parallel fractures are influenced by intrusions, mineralization, and ascending hydrothermal fluids.

Outcrop units in the study area are as follows:

\subsection{Shale-siltstone and sandstone Jurassic unit}

Shemshak formation of Jurassic age with relatively high extension and fault boundary with Triassic containing black shales and fine-grained olive-green to dark gray sandstones and between calcareousshale layers with plant fossil fragments is. This unit is the oldest outcrop in the Kamo Index region (Fig 1a). The rocks of this unit include siltstone-sandstone and shale with a calcareous interlayer. The lower part of the formation, which forms the core of the Kamo anticline, consists mainly of siltstone and 
sandstone that have been altered to quartzite and the upper part consists mainly of dark shale with calcareous thin layers.

\subsection{Cretaceous unit}

Cretaceous orbitolina-bearing limestones are found on the Jurassic formation, creating an unconformity, which begins in the Kamo area with a basal conglomerate, indicating Cretaceous progression (Fig 1b). However, this conglomerate section is not well-observed due to the presence of debris and low thickness in the study area. In the southwestern part and outside the Kamo area, this section is about 40 to $60 \mathrm{~m}$ thick. In this area, the Cretaceous unit forms the upper part of Kamo, but the true thickness of this unit cannot be determined due to the action of faults and erosion. Skarn is formed in the parts where this unit is in contact with the intrusive mass (Fig 1c). In general, the sequence of rocks in this period comprises limeshale-sandstone and marl, which are most extensively related to orbitolina-bearing lime, sandy-marl, and lower Cretaceous shale units (Fig 1d), forming an unconformity mediated by the conglomerate layer over the Jurassic unit (a simple geological map of the area is presented in Fig 2).
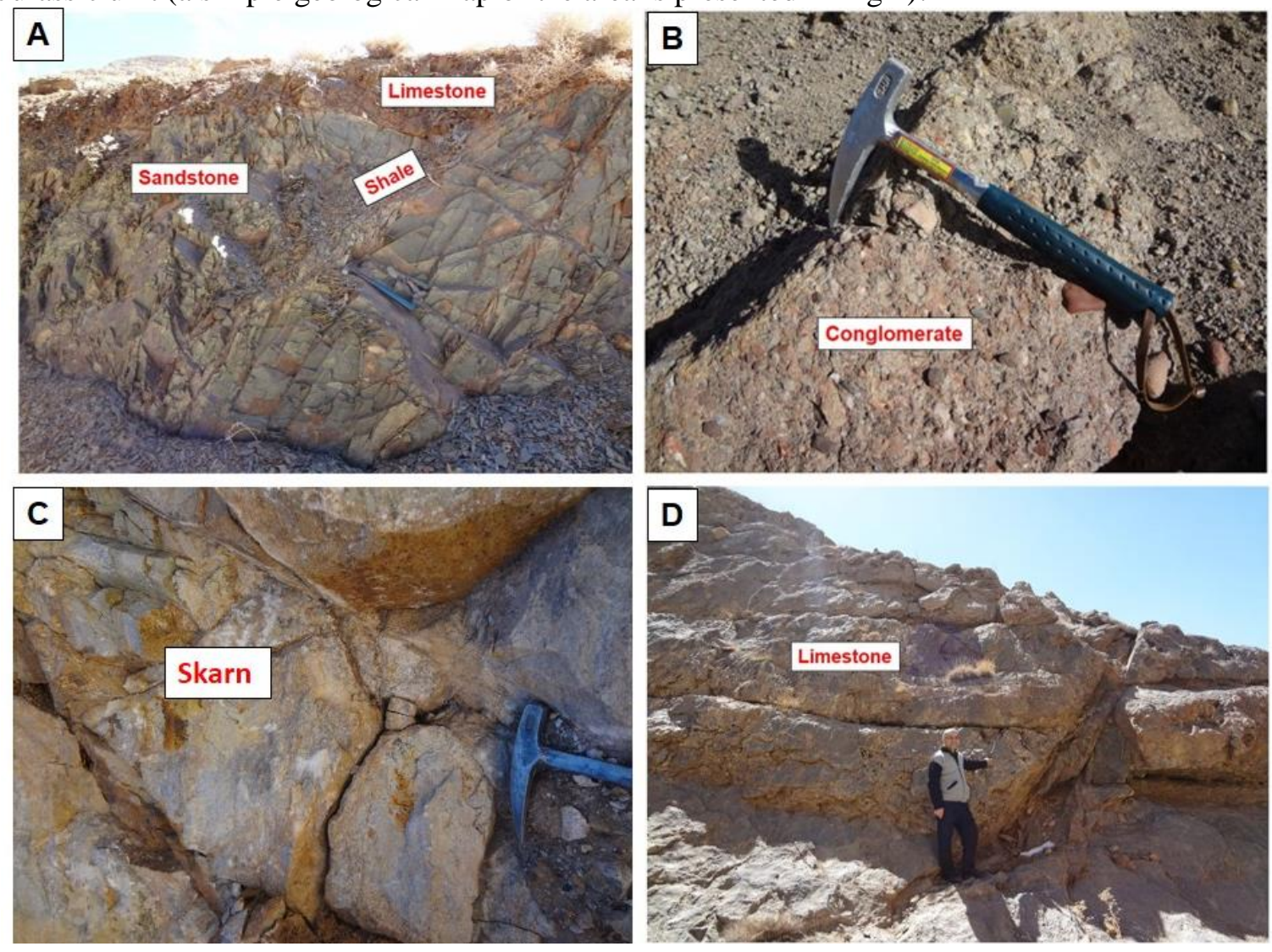

Fig 1. Outcrop units in the Kamo area: a) Outcrop of sandstone with layers of shale and lime; b) Conglomerate outcrop (in the northern part of the region); c) Formation of skarn in the limestone of the area (in the center of the area on the boundary of the iron ore deposit); d) Outcrops of calcareous rocks and sandstone units in the Kamo area (in the northern part of the northwest view) 


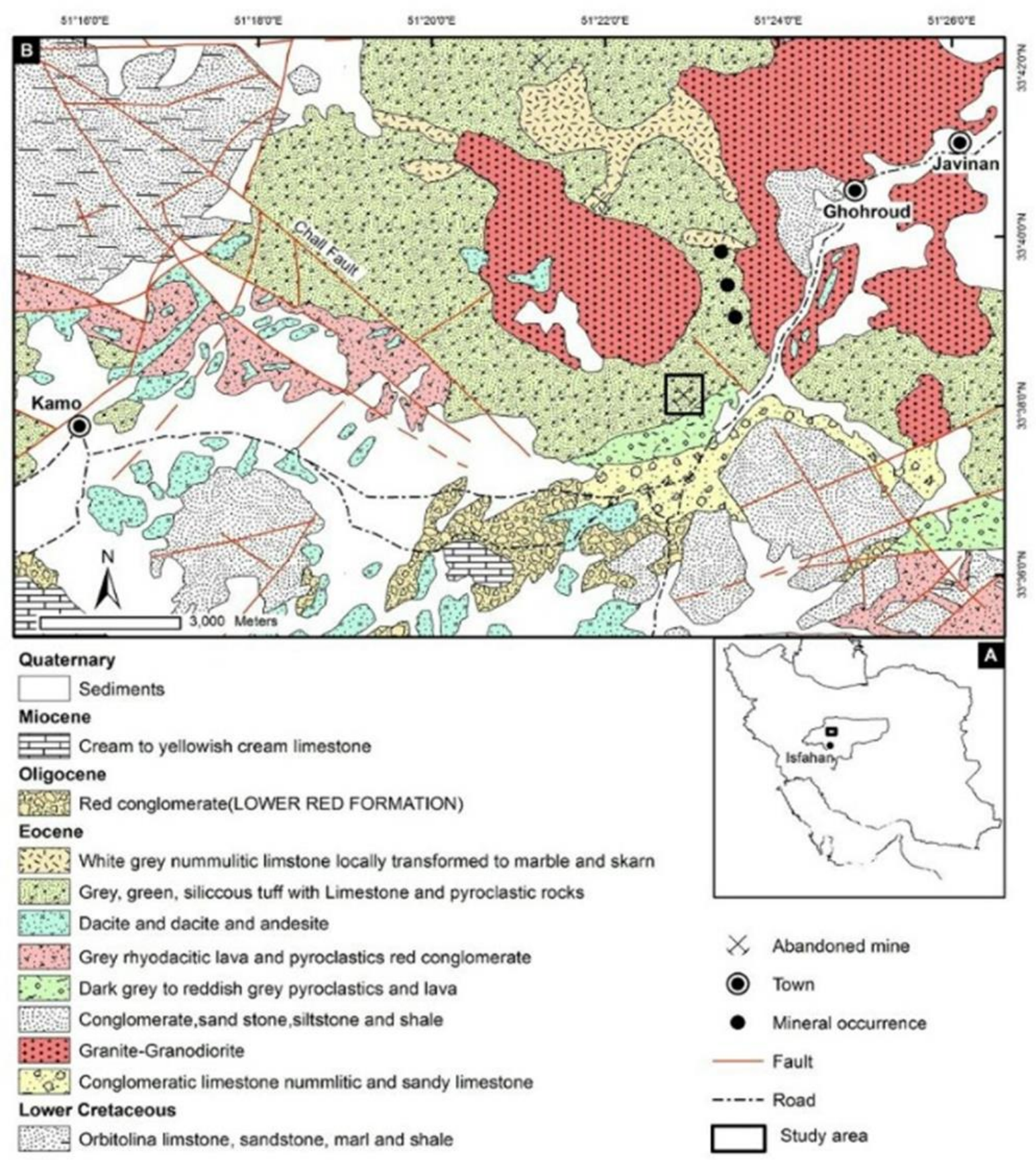

Fig 2. Geological map of the study area (Rokhbar et al., 2015).

\subsection{Magmatism in the Kamo region}

The magmatic activity in Kamo consists of a series of intrusive rocks with granodiorite composition in the central and western parts and a number of dykes with andesite and dacite compositions in the western and southeastern parts of the region. In the estimation of its age, geological survey of Iran indicates that the intrusion is from the Miocene (Borna and Janessary 1993). Extrusive materials such as tuff or other volcanic materials are not observed in the study area, but some are seen outside it. According to Bagheri, granodiorite masses have a microscopic granular texture and are porphyroid in some parts, with 60 to $65 \%$ 
plagioclase from andesine to oligoclase (Bagheri 1998). The dykes have a porphyritic texture and the main constituent mineral is plagioclase (andesine), composed of 10 to $20 \%$ biotite.

\section{RESEARCH FINDINGS}

\subsection{Microscopic mineralogy}

Mineral and ore assemblages in the region include chalcopyrite, pyrite, marcasite, and magnetite as primary minerals. Malachite, boronite, covellite, chalcocite, hematite, goethite, and hydrous iron oxides of secondary origin have been formed due to oxidation and surface processes. The primary textures are granular, disseminated, vein-shaped, and layered and the secondary textures are boxed and martitized, shear zones, replacement, and vein. Tectonic, metamorphic, and oxidation factors are involved in the formation of the mentioned textures. Due to the tectonic activity of this area and the presence of faults because of these activities after mineralization, replacement, vein, and shear textures are observed. Owing to hydrothermal fluids, these minerals have weathered and altered, and secondary minerals such as bornite, chalcocite, goethite, and hematite have been spread around the chalcopyrite and martite within the magnetite. In the area of pyrite-chalcocite-pyrolosite mineralization, iron oxides (magnetite, goethite, and hematite) are seen (Fig $3 a \& b$ ). The presence of minerals such as chalcocite indicates biogenic surface alteration. By leaching of copper solutions and their entry into a reduction environment, generally below the water table, conditions for calcite deposit mineralization on the margin of pyrite are provided.

Chalcocite has variable amounts of copper in its structural formula (20-80\% mean copper content) (Liu et al. 2017). It is also formed along with calcite, covellite, and bornite on the surface. Covellite is dark blue in color and has a strong polycrystalline structure and high anisotropy. The formation of covellite in the studied deposit can be attributed to the addition of sulfur to chalcopyrite and the formation of pyrite and covellite:

$$
\mathrm{CuFeS}_{2}+\mathrm{S} \Rightarrow \mathrm{FeS}_{2}+\mathrm{CuS}
$$

Subsequently, when the water table is lowered and environmental conditions change to the oxidized state, we will observe the decomposition of the previous minerals and the formation of minerals such as iron and manganese oxides (pyrolosite), chalcopyrite, boronite, chalcocite, and covellite (Fig 3c). Boronite is a copper ore and widely stored in hydrothermal deposits as well as skarns with more abundant chalcopyrite. Chalcopyrite and boronite are both commonly replaced by chalcocite and covellite in the biogenic surface enrichment zone. The acronyms used to name the minerals in the microscopic images were taken from the names and acronyms used by "Whitney and Evans" (Whitney and Evans 2010). The main ore magnetite is mineralization mostly with a massive texture. As a result of the martitization process, parts of the magnetite have become hematite along the fractures and clefts. According to Ramdohr, martitization is considered a process after ore formation caused by the temperature drop in the intrusive mass and the influx of low temperature and oxide fluids (Ramdohr 1980). Magnetite with the chemical composition of $\mathrm{Fe}_{3} \mathrm{O}_{4}$ is a component of spinels. This oxide mineral is more stable than hematite at high temperatures and lower oxygen concentrations (Fig 3d). Hematite $\left(\mathrm{Fe}_{2} \mathrm{O}_{3}\right)$ contains $70 \%$ iron and $30 \%$ oxygen, but sometimes contains some manganese and titanium as well. At temperatures above $811{ }^{\circ} \mathrm{C}$, there is a complete series of solid solutions between ilmenite and hematite (Harrison 2009). Hematite often shows corrosion at high temperatures. The conversion of hematite to pyrite in a hydrothermal environment is a common phenomenon. Weathering causes hematite to become goethite, which is a slow phenomenon. The structural properties of hematite minerals depend on the conditions of their formation. This mineral is highly inclined to form (is mainly as ediomorph form. ediomorphically. Hematite formed at high temperatures usually appears in the form of large crystals and is isometric in metasomatic adjacent conditions. The conversion of magnetite to hematite means that martitis and hematite to magnetite are in vitro an oxidation-reducing reaction that occurs in the presence of oxygen or without oxygen (Fig 3d) 
(Rasa 2006). In fact, there has been some growth between martianite, magnetite, and pyrite before decay according to the reaction:

$$
6 \mathrm{FeS}+4.6 \mathrm{O} 2 \mathrm{Fe} 3 \mathrm{O} 4+3 \mathrm{FeS} 2
$$

This means that divalent iron ions of sulfur and oxygen were present in the environment so that in the $S$ Fe system, pyruvate formed during the equilibrium between iron and sulfur. In reaction to oxygen, magnetite and pyrite also appear. This may be a reason for the mantle origin of magnetite and sulfur. One of the common phenomena in this iron ore deposit is the occurrence of magnetite martite, which itself is a cause of oxidative conditions (Fig 3D). According to the previous studies and the studies of mineral assemblages in the area and their generative relationships, it can be concluded that a series of granitoid rocks more with monzodiorite than with monzogranite composition have affected their surrounding rocks and the effects of temperature have caused them to undergo metamorphosis and deformation. At this time, the primary minerals have created a series of mineral parageneses related to metamorphic alterations due to the migration of elements and the new thermodynamic equilibrium.

These minerals include pyroxene, amphibole plagioclase, garnet, quartz, and minerals such as magnetite, hematite, chalcopyrite, pyrite, and chalcocite along with a series of oxide minerals such as goethite, malachite, and clay minerals.
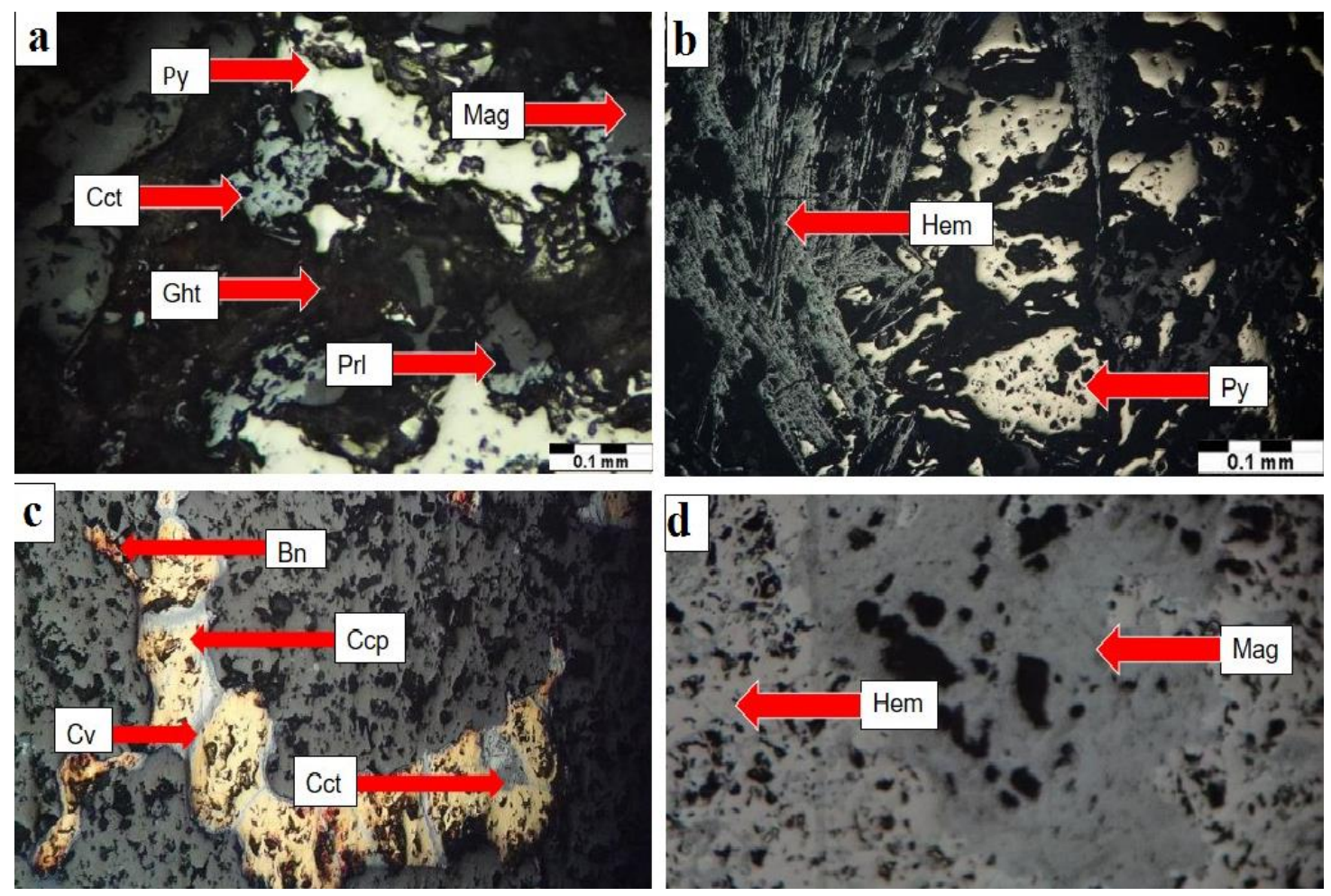

Fig 3. a) Magnetite (Mag), Goethite (Gth), Chalcocite (Cct), Pyrite (Py), Pyrolozite (Prl); b) Hematite (Hem) with blade and box structure of pyrite (Py); c) Chalkopyrite minerals (Ccp), Calcitocyte (Cct), Bornite (Bn), Covellite

(Cv); d) Martian magnetite (Mag) and Hematite (Hem) formation (light shines from above in all images).

\subsection{Correlation between elements in litho-geochemical samples}

In a geochemical study, the concentration of some elements in a series of geochemical samples is often measured because each group of elements is more or less sensitive to a series of environmental conditions. Understanding the interrelationship and genetic dependence between different elements can lead to a better perception of the changes in geochemical environments. In addition, genetic accumulation of some elements may be regarded as a direct sign in interpreting the type of deposition that may be present in the 
area. On the contrary, the accumulation of some elements may indicate anomalies that are trivial and misleading. Understanding the genetic interdependencies among the elements provides the information needed to better understand the geochemical data. Therefore, one of the statistical techniques that should be used in geochemical exploration is to determine the correlation between a pair of variables that are likely to be correlated (Levinson 1980). Diagrams in which oxides are plotted against $\mathrm{SiO}_{2}$ are often known as "Harker diagrams." These diagrams are the oldest variation diagrams and one of the most commonly used methods to represent the data for the major elements. $\mathrm{SiO}_{2}$ is usually chosen as the plotting parameter for many igneous rock series and sedimentary rocks with variable quartz values, because quartz is the main constituent of the rock and exhibits variations more than other oxides. For this purpose, the Harker diagram of the main oxides versus silica is drawn to investigate the correlation of the elements. Oxides such as $\mathrm{Fe}_{2} \mathrm{O}_{3}$ have a negative correlation with $\mathrm{SiO}_{2}$ and decrease with increasing $\mathrm{SiO}_{2}$ content. This negative trend coincides with the subtraction crystallization process. Ferromagnesian

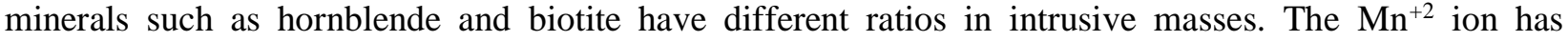
geochemical properties similar to those of $\mathrm{Fe}^{+2}$ and to some extent $\mathrm{Ca}^{+2}$; it is usually replaced by magmatic alterations (Fig 6).

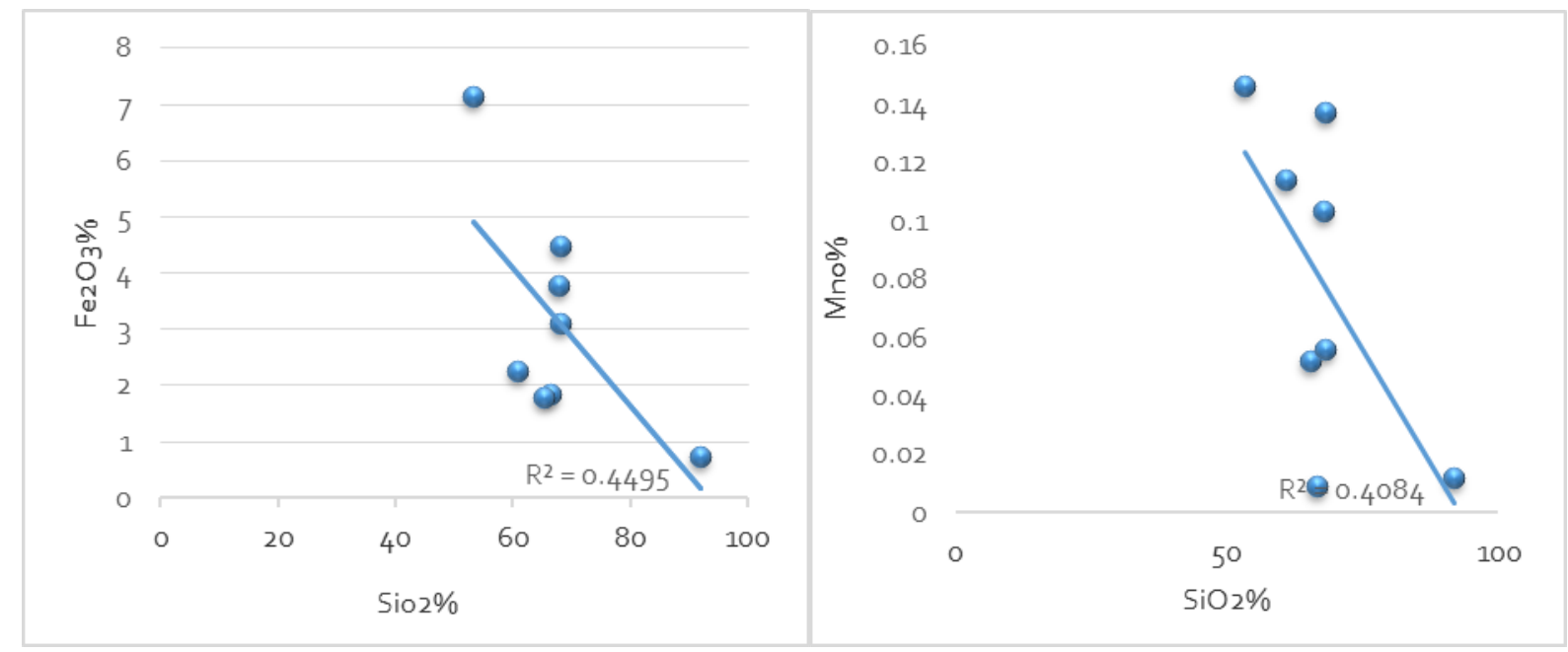

Fig 4. Correlation diagrams for $\mathrm{Fe}_{2} \mathrm{O}_{3}$ and $\mathrm{MnO}$ oxides versus $\mathrm{SiO}_{2}$ oxide.

The correlation charts of iron and manganese oxides with titanium oxide silica in igneous rocks are mainly Ilmenite. It can replace $\mathrm{Al}$ and is therefore present in pyroxene, hornblende, and biotite. It is ejected from highly siliceous magmas as titanite minerals (Sphene). This element has a direct relationship with the amount of silica in the study area (Fig 7). Because of the high amount of silica, it is generally observed as sphene in this range. As $\mathrm{SiO}_{2}$ content increases, $\mathrm{CaO}$ content declines (Fig 7). This oxide enters the anorthite and hornblende structures, which crystallize in the early stages of magmatic subduction. Some of the $\mathrm{CaO}$ forms apatite minerals with $\mathrm{P}_{2} \mathrm{O}_{5}$. The positive correlation coefficient of $\mathrm{CaO}$ with $\mathrm{P}_{2} \mathrm{O}_{5}$ confirms this phenomenon. 


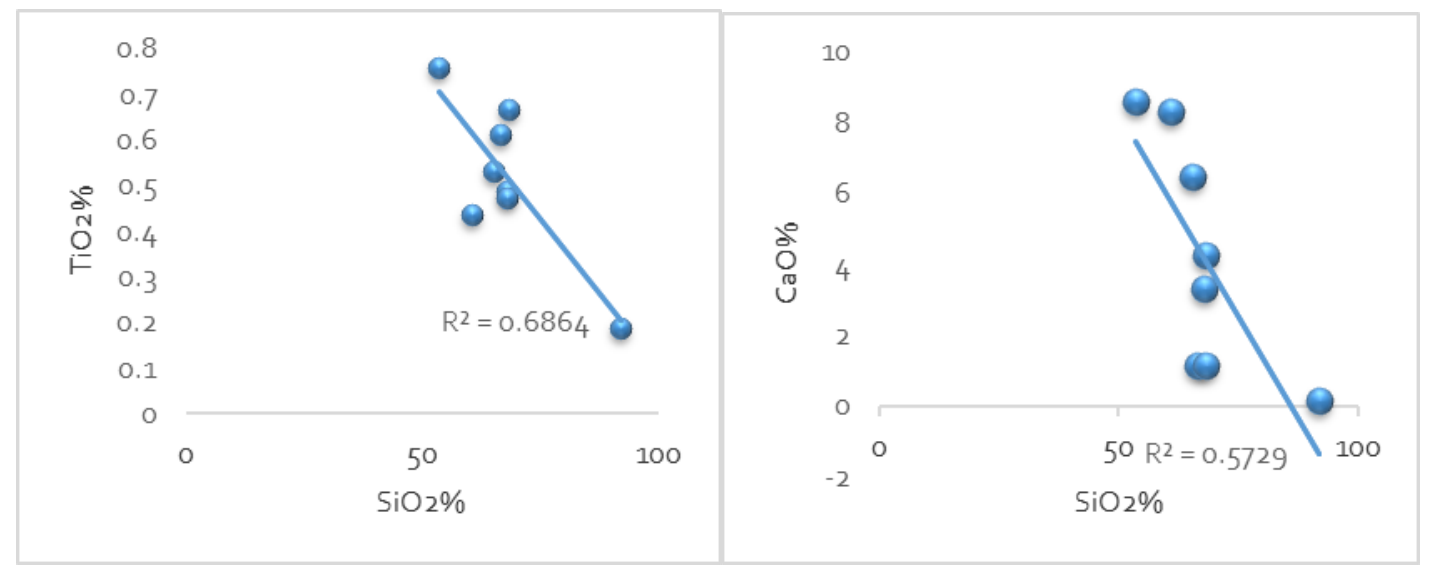

Fig 5. Correlation diagrams for $\mathrm{TiO}_{2}$ and $\mathrm{CaO}$ oxides versus $\mathrm{SiO}_{2}$ oxide.

The amounts of potassium and sodium are positively correlated with the amount of silicon in magma (Fig 8) and this process is related to magmatic (Bowen's series) processes associated with plagioclases, feldspars, and ferro-magnesium minerals such as pyroxene, amphibole, and biotite. As magma crystallization progresses, the amounts of sodic and potassic elements for both the discontinuous series (ferro-magnesium series) and the continuous series (feldspar and plascioclase series) gradually increase. In other words, the magma gradually becomes acidic. The amount of aluminum is negatively correlated with silicon content, meaning that the amount of $\mathrm{Al}_{2} \mathrm{O}_{3}$ will decrease as the amount of silicon increases. As mentioned, in accordance with the magmatic crystallization series, the ferro-magnesium-bearing and plagioclase minerals are formed with a small amount of silica and a large amount of aluminum and, in the final stages of crystallization, aluminum content decreases.

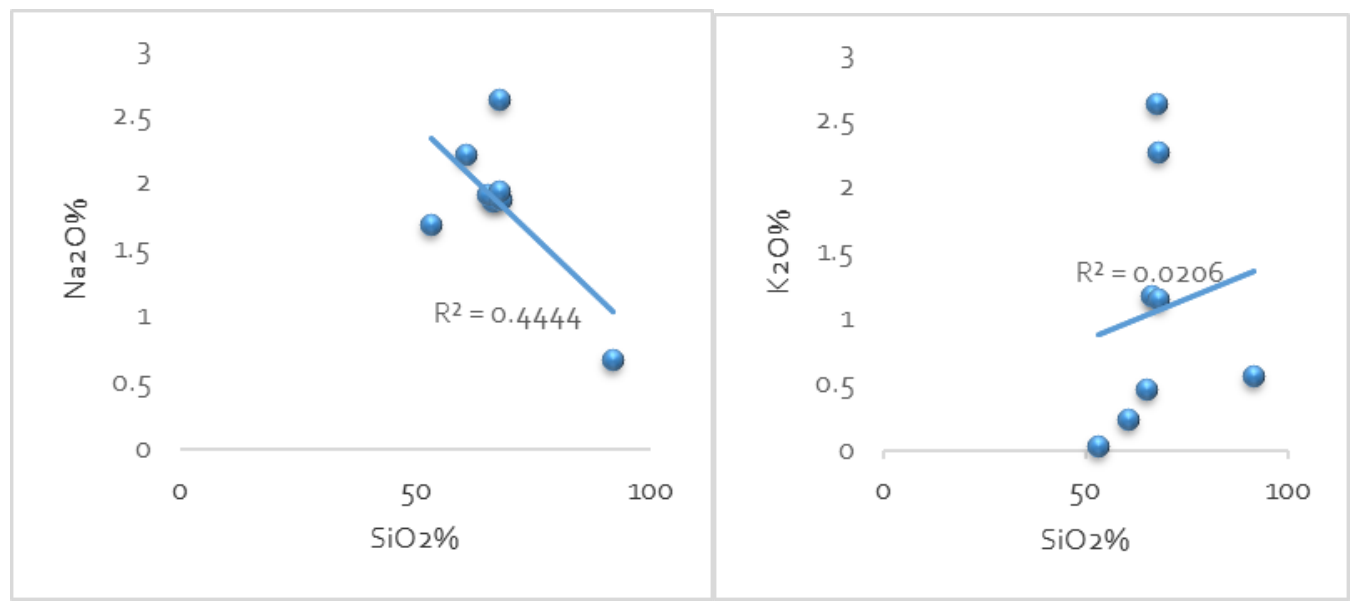

Fig 6. Correlation diagrams for $\mathrm{Na}_{2} \mathrm{O}$ and $\mathrm{K}_{2} \mathrm{O}$ oxides versus $\mathrm{SiO}_{2}$ oxide.

\subsection{Correlation of iron with sulfur and phosphate}

One of the important factors in estimating iron deposits is the identification of the relationship among iron, sulfur, and phosphorous in the study area. For this purpose, the relationship between two variables of iron, sulfur, and phosphate in different rocks is investigated. Studies have shown that there is no definite relationship between iron content and sulfur and phosphate contents (Fig 9).

and sulfur and phosphate contents (Fig 9). 


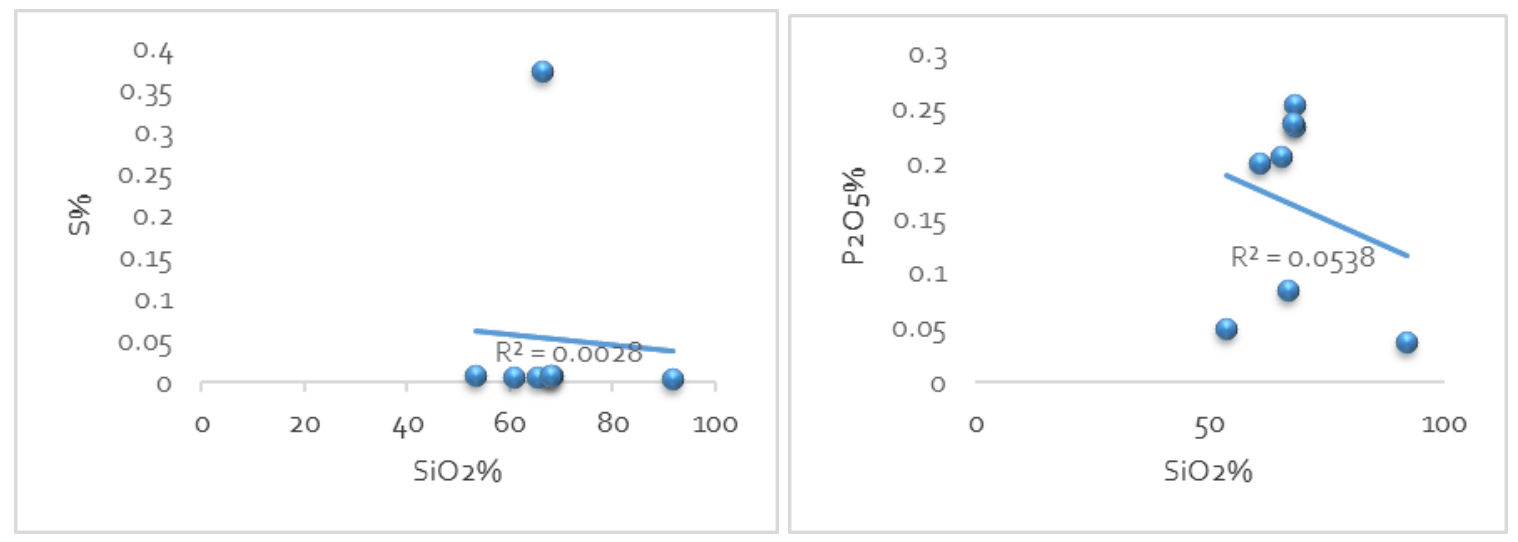

Fig 7. Correlation diagrams for $\mathrm{S}$ and $\mathrm{P}_{2} \mathrm{O}_{5}$ oxide versus $\mathrm{SiO}_{2}$ oxide

\subsection{Relationship between alteration and mineralization}

The Kamo region is reported to be severely faulted, tectonized, and fragmented. The presence of fractures is a very effective factor on the passage of hydrothermal fluids and lithogenic minerals. As a result, alterations are very common in areas severely affected by tectonics. Furthermore, the alteration process has been effective in the formation of high-grade iron masses in the Kamo area so that wherever the intensity of alterations has increased, iron masses are more concentrated. Relevant information in this regard can easily be obtained by field observations. The contributions of propylitic, limonite, and clay alterations are also important in the formation of iron deposits in this region. Figs 4 and 5 show pictures of altered outcrops in the area.
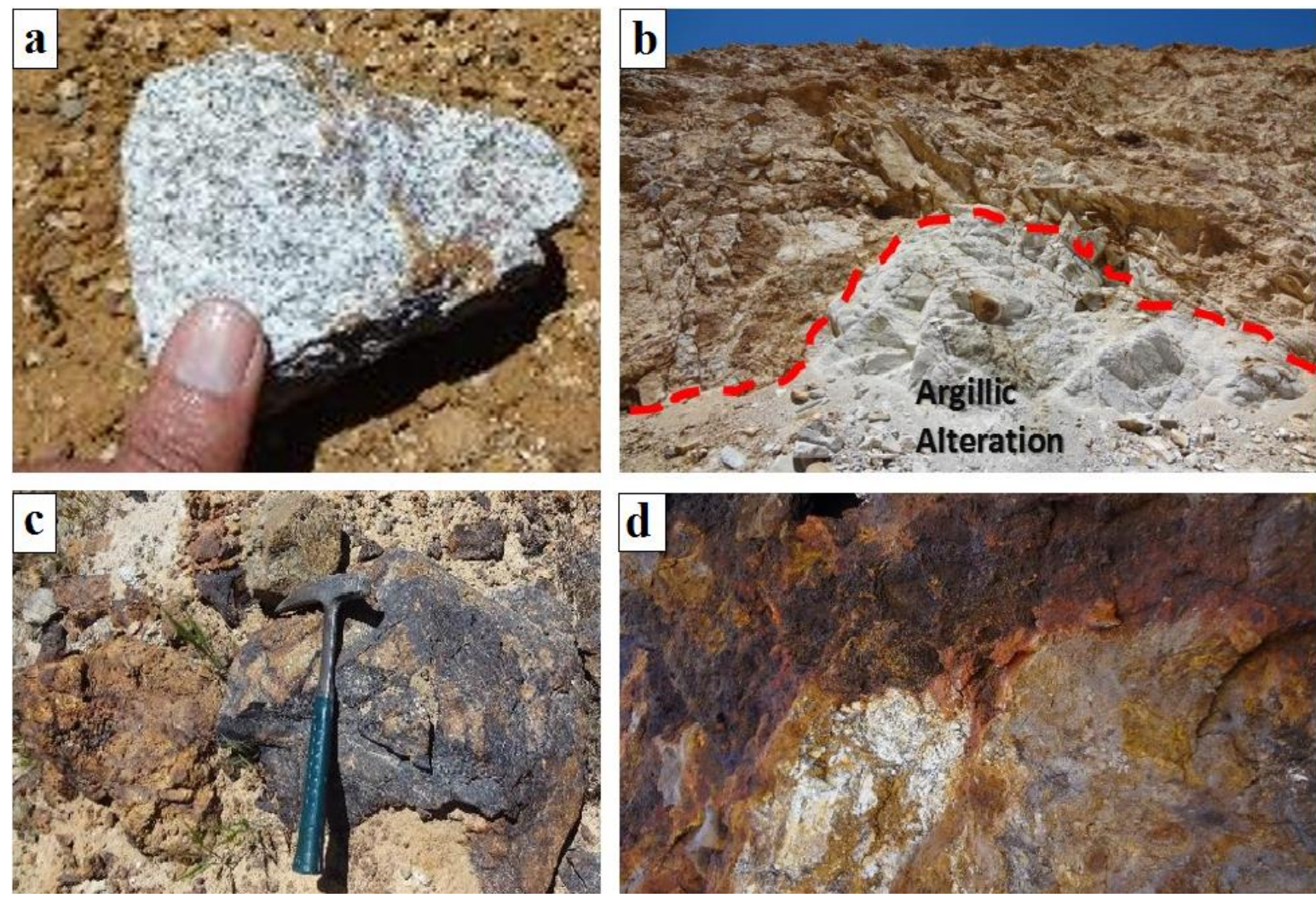

Fig 8. Outcrop of alteration zones in the study area: a) Serecitation of primary rocks; b) View of argillic alteration zone and accumulation of clay minerals and iron oxides; c) Hematite alteration; d) A close-up view of limonite and goethite alterations 

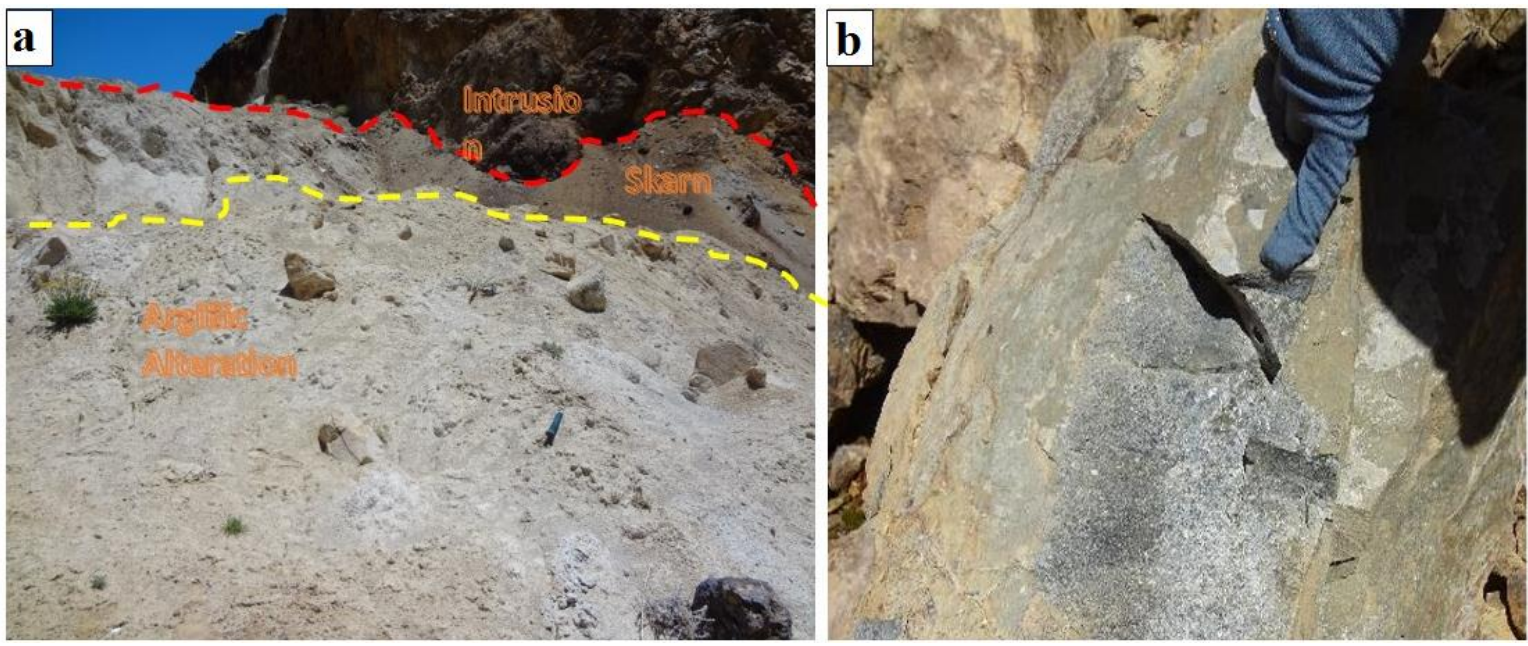

Fig 9. Outcrop of alteration zones in the study area: a) A view of skarn and argillic alterations; b) A close-up view of propylitic alteration in the area

\subsection{Geochemical properties of Kamo granitoids}

Granitoids are the most abundant igneous rocks within the continental crust and found in batholiths and stocks. Granitoids have different types depending on the tectonic setting. Kamo's granitoids have been introduced as the source rock for Kamo iron ore deposit.

The average percentage of major oxides of lithofacies is shown in Table 1 according to field and laboratory studies as well as numerical calculations. The average amount of aluminum oxide in the igneous rocks of the Kamo region is 15.31 percent. As mentioned earlier, the ratio of aluminum oxide to alkaline oxides is more than one. Therefore, the type of magma that has created the Kamo iron ore deposit is classified in the super-aluminum series according to Karimpour's classification (Karimpour and Saadat 1998). Sub-alkaline granitoids of the region are related to the continental subduction zone orogenic series.

\subsection{Determining magmatic series}

Chappell and White consider the origin of S-type granitic magma to be from the crust and the origin of type-I granitic magma to be from lower than the continental crust, as result of magmatic subtraction. They divide igneous rocks into three series according to the origin and tectonic positions:

1. Super-alkaline series,

2- Alkaline series, and

3. Sub-alkaline series (Chappell and White 2001).

In each series, various types of igneous rocks are found. Mineralogical and chemical compositions of igneous rocks can be used to determine these series. First, super alkaline rocks can be separated if the total mol $\left(\mathrm{Al}_{2} \mathrm{O}_{3}<\left(\mathrm{K}_{2} \mathrm{O}+\mathrm{Na}_{2} \mathrm{O}\right)\right.$ is super alkaline. 
Table 1. Chemical decomposition results by method XRF

\begin{tabular}{ccccccccccccc}
\hline Element & $\mathrm{SiO} 2$ & $\mathrm{~A} 12 \mathrm{O} 3$ & $\mathrm{Fe} 2 \mathrm{O} 3$ & $\mathrm{CaO}$ & $\mathrm{Na} 2 \mathrm{O}$ & $\mathrm{K} 2 \mathrm{O}$ & $\mathrm{MgO}$ & $\mathrm{TiO} 2$ & $\mathrm{MnO}$ & $\mathrm{P} 2 \mathrm{O} 5$ & $\mathrm{~S}$ & $\mathrm{LOI}$ \\
& $\%$ & $\%$ & $\%$ & $\%$ & $\%$ & $\%$ & $\%$ & $\%$ & $\%$ & $\%$ & $\%$ & $\%$ \\
\hline $\mathrm{S} 1$ & 60.77 & 16.84 & 2.24 & 8.34 & 2.21 & 0.23 & 1.89 & 0.437 & 0.114 & 0.199 & 0.006 & 6.25 \\
$\mathrm{~S} 3$ & 66.54 & 19.11 & 1.84 & 1.16 & 1.86 & 1.16 & 0.28 & 0.611 & 0.009 & 0.083 & 0.373 & 5.69 \\
$\mathrm{~S} 97$ & 65.31 & 16.62 & 1.78 & 6.48 & 1.91 & 0.46 & 2.05 & 0.53 & 0.052 & 0.206 & 0.006 & 3.96 \\
$\mathrm{~S} 112$ & 68.26 & 16.78 & 4.48 & 1.16 & 1.87 & 1.14 & 1.57 & 0.665 & 0.137 & 0.253 & 0.007 & 3.4 \\
$\mathrm{~S} 115$ & 68.07 & 15.63 & 3.09 & 4.26 & 2.62 & 2.25 & 0.93 & 0.487 & 0.056 & 0.233 & 0.008 & 1.94 \\
$\mathrm{~S} 118$ & 53.42 & 16.74 & 7.14 & 8.6 & 1.68 & 0.02 & 6.24 & 0.758 & 0.146 & 0.049 & 0.008 & 4.97 \\
$\mathrm{~S} 122$ & 91.84 & 4.79 & 0.72 & 0.14 & 0.67 & 0.55 & 0.19 & 0.185 & 0.012 & 0.036 & 0.004 & 0.72 \\
$\mathrm{~S} 138$ & 67.89 & 16.03 & 3.77 & 3.32 & 1.93 & 2.61 & 1.06 & 0.472 & 0.103 & 0.236 & 0.007 & 1.98 \\
\hline
\end{tabular}

AFM plot (Irvine and Baragar 1971)

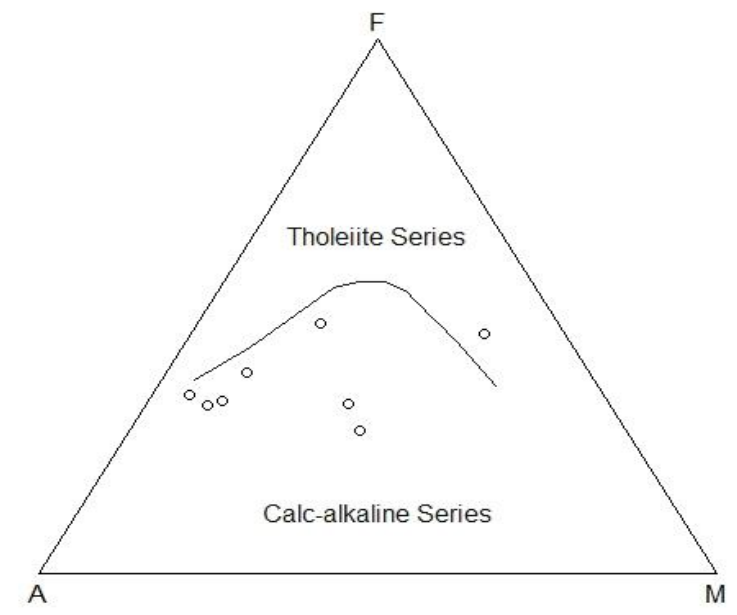

Fig 10. AFM diagram for samples from Kamo deposit (Irvine and Baragar 1971)

The sub-alkaline series contains tholeiitic and calc-alkaline series, but the two series can be separated by their shapes. According to Fig 10, the AFM triple diagram of Kamo deposit is in the range of calc-alkaline series. Studies of decomposed iron samples in the Kamo region show that most of the samples are in the sub-alkaline series and the chemical and mineralogical composition of the magma from this series is calc-alkaline with high iron content. Fig 11 shows $\mathrm{CNK}$ position against $\mathrm{A} / \mathrm{CNK}$ in terms of aluminum content in the Kamo region. 


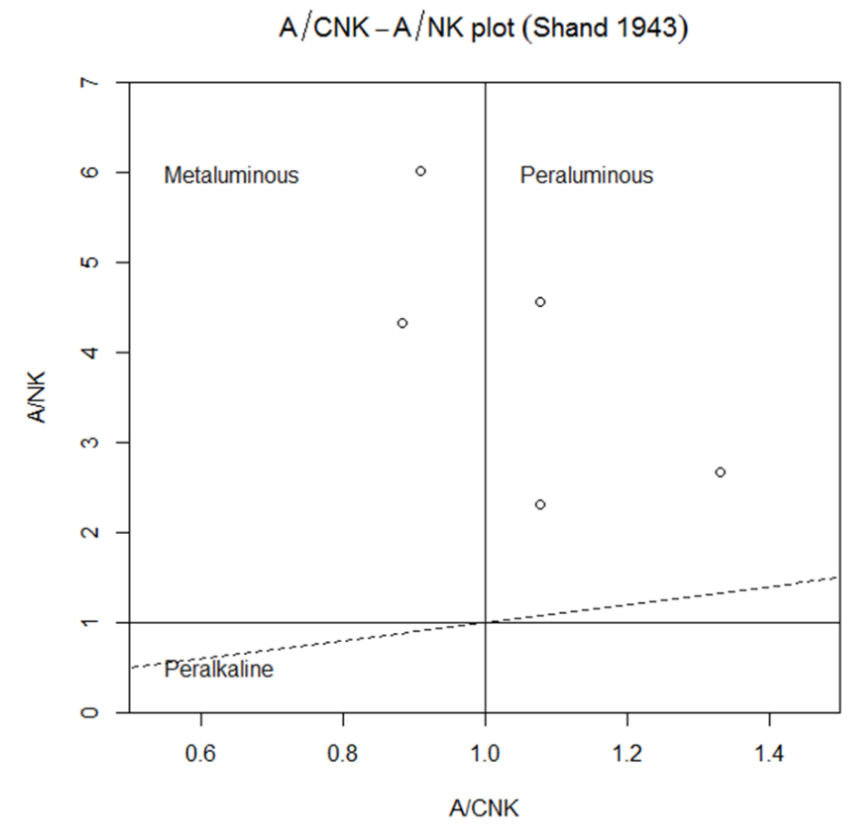

Fig 11. ANK vs. A/CNK diagrams for the amount and type of aluminum in Kamo region

Thorium-cobalt ratio diagrams (Hastie et al. 2007) (Fig 12) also confirm the presence of calc-alkaline and "peralumina" (Fig 13) magmatic series in Kamo region.

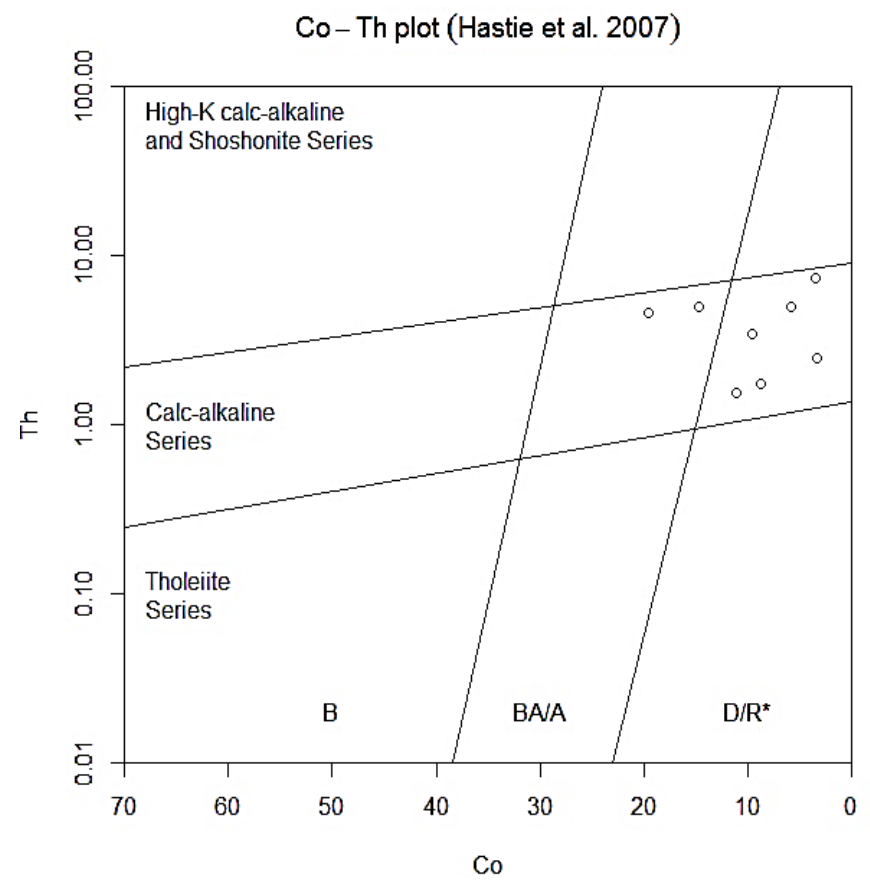

Fig 12. Diagram of the Kamo granitoids type (Hastie et al. 2007) 


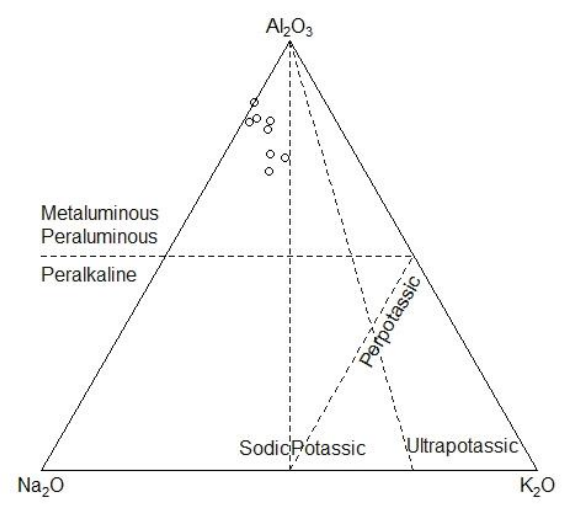

Fig 13. the amount of aluminum in magma from Kamo region

\subsection{Sulfur isotopic composition in the Camus reserve}

Since the largest volume of sulfide ores in the region was composed of pyrite minerals, 6 samples of pyrite sulfide ore were taken by isotopic investigation into sulfur (Fig 9). After initial preparation, including isolation and purification, samples were sent to G.G. Hatch Isotope Laboratory in Canada. . The samples were weighed by the laboratory at least twice using tin capsules with a sample of tungsten oxide for minerals and organic sulfur. They were tested in an Elementar Isotope Analyzer through combustion at $1800{ }^{\circ} \mathrm{C}$. The exhaust gases were purified and separated by helium. $\mathrm{SO}_{2}$ gas was transferred to a Delta Plus XP Thermo Finnigan mass spectrometer to determine sulfur-34 content. Analytical accuracy was $\pm 0.002 \%$. The data were normalized (Tables 2 and 3 ) and linear modification was applied to the cases in which the weight range necessitated modification.

Table 2. Standards used in the analysis

\begin{tabular}{|c|c|c|}
\hline Sulfides & & $34 \mathrm{~S}$ \\
\hline IAEA-S1 & S-1 & -0.3 \\
\hline IAEA-S2 & S-2 & 22.7 \\
\hline AG-2 & S-6 & -0.71 \\
\hline
\end{tabular}

Table 3. Results of analysis for sulfur in pyrite from Kamo area

\begin{tabular}{|c|c|c|c|c|c|}
\hline Sample ID & Weight (mg) & $\begin{array}{c}\delta^{34} \mathrm{~S}- \\
\%, \mathrm{CDT}\end{array}$ & $\% \mathrm{~S}$ & Comment & Hatch Lab ID \\
\hline $134-1$ & 0.125 & 3.4 & 26.8 & Pyrite & B1819-563-001 \\
\hline $134-2$ & 0.117 & 5.8 & 40.3 & Pyrite & B1819-563-002 \\
\hline $134-2$ & 0.136 & 6.4 & 40.4 & Pyrite & B1819-563-003 \\
\hline $134-3$ & 0.120 & 4.3 & 34.4 & Pyrite & B1819-563-004 \\
\hline $134-4$ & 0.140 & 4.1 & 28.1 & Pyrite & B1819-563-005 \\
\hline S3 & 0.112 & 2.8 & 18.4 & Pyrite & B1819-563-006 \\
\hline
\end{tabular}


The lowest measured value in the pyrite samples was $8.2 \%$ and the highest value was $4.6 \%$. The mean $\delta^{34} \mathrm{~S}$ was $4.4 \%$. As can be seen, the measured $\delta^{34} \mathrm{~S}$ values in the samples have a relatively wide variation range (Fig 14). These values indicate that some part of the sulfur effective in the formation of the deposit, in addition to igneous origins, originates from the heavy sulfur of the continental origin. The absence of sulfate minerals in the rocks indicates that the pyrite sulfur isotopes and the mineral composition of the rocks have the isotopic composition $\left(\delta^{34} \mathrm{~S} \Sigma \mathrm{S}\right)$ of the average rock mineralization fluid (Zheng and Chen 2000).

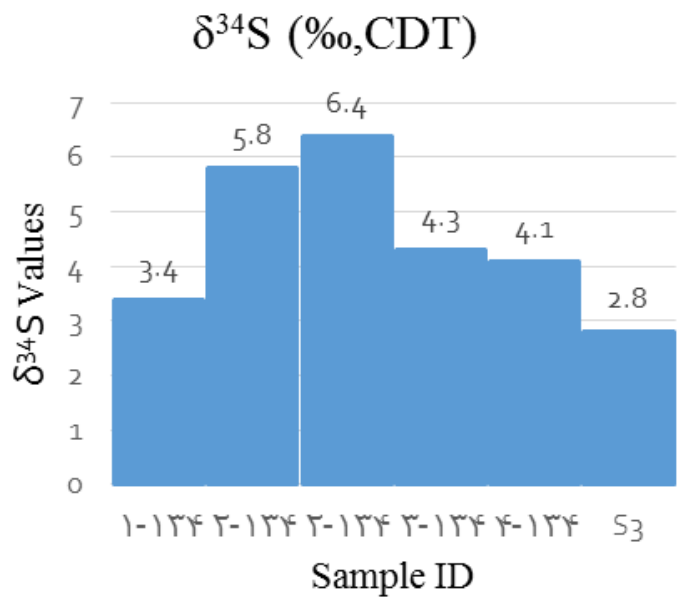

Fig 14. Frequency diagram for $\delta^{34} \mathrm{~S}$ values of pyrite minerals in the Kamo deposit

Fig 15 shows the range of $\delta 34 \mathrm{~S}$ variations in different mineralization systems. According to this graph, the isotopic values of the Kamo sulfur deposit overlap with the sulfides of skarn deposits and submarine hydrothermal deposits. According to mineralogical and lithological evidence as well as geochemical findings, this deposit does not resemble submarine hydrothermal deposits. Therefore, the most probable conjecture based on isotopic results is a skarn-type deposit.

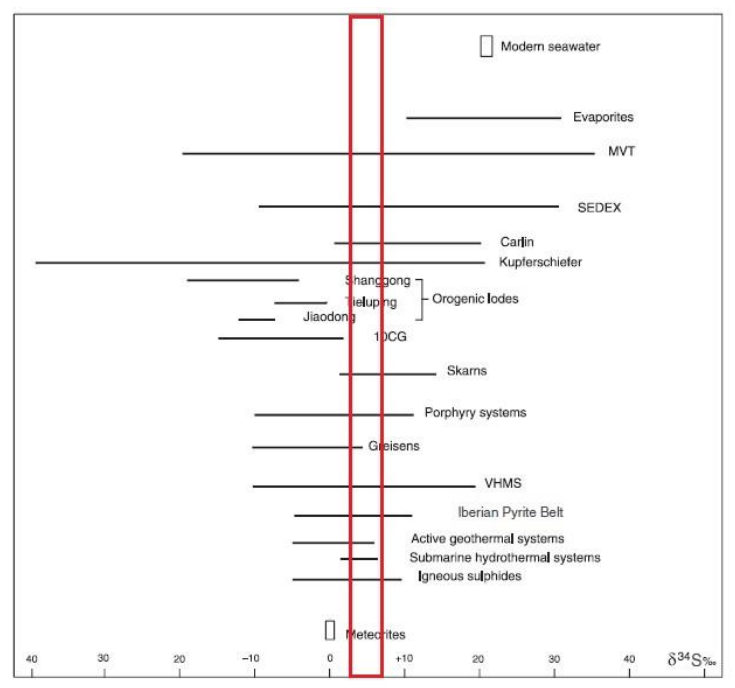

Fig 15. Changes in $\delta 34$ S sulfides in some mineral systems and deposits (Pirajno 2009) The red box shows the range of isotopic changes in the Kamo deposit. 


\section{CONCLUSION}

According to studies of mineral assemblages in the region and their generative relationship, it can be concluded that a collection of granitoid rocks with the composition of quartz monzodiorite to monzogranite have affected their adjacent rocks and, by their thermal effect, transformed them. At this time, their primary minerals have created a collection of mineral parageneses related to metamorphic alterations as a result of the migration of elements and the new thermodynamic equilibrium. The Kamo area is highly faulted, tectonized, and crushed. The presence of these fractures is a very effective factor on the passage of hydrothermal and ore-forming fluids so that alteration is increased in the areas with tectonic activity. Furthermore, the alteration process has been effective in the formation of high-grade iron masses in the Kamo area, with the iron masses being more concentrated wherever alteration intensity has increased. These patterns can easily be obtained by field observations. The contributions of propylitic, limonite, and clay alterations are also important in the formation of iron deposits in this region. Subalkaline granitoids of the region are related to the orogenic series of continental subduction zone. Studies of decomposed iron samples from Kamo show that most of the samples are in the sub-alkaline series and the chemical and mineralogical composition of magma from this series is high alkaline calcite. The measured $\delta^{34} \mathrm{~S}$ values in the samples have relatively wide variation ranges. These values indicate that a part of the sulfur effective in the formation of this deposit, in addition to igneous origins, comes from the heavy sulfur of the continental origin. According to the mineralogical, lithological, and geochemical evidence as well as the results of isotopic analyses, this deposit is of the Skarn type.

\section{REFERENCES}

Anwar, A., Shawki, N., \& Ghaleeb., A. (2013). Landsat ETM-7 for lineament mapping using automatic extraction technique in the SW part of Taiz Area, Yemen. Global Journal of Human Social Science (B), XIII, 35-38.

Borna, B., Janessary, M. (1993). Systematic Discovery Plan Report of Exploration Operations on Map 1/100000 Kashan, (Persian).

Badr, A. (2012). Petrological studies of skarn from Eastern part of Ghohroud granodiorite (SE Ghamsar, Isfahan Province), M.Sc. Thesis. University of Isfahan, 157p, (Persian).

Bagheri, H. (1998). Preliminary discoveries and investigation of copper mineralization genesis in Kamo Mineral Index (Isfahan), Ph.D. Thesis, Kharazmi-University. 117p, (Persian).

Baratian, M., Arian, M.A., \& Yazdi, A. (2020) Petrology and Petrogenesis of Siah Kooh volcanic rocks in the eastern Alborz, GeoSaberes, v . 11, p. 349-363. DOI: https://doi.org/10.26895/geosaberes.v11i0.980

Barton, M.D., \& Johnson, D.A., (2000). Alternative brine sources for Fe- oxide (-Cu- $\mathrm{Au}$ ) systems: Implications for hydrothermal alteration and metals. In: T. M. Porter (Editor), Hydrothermal Iron Oxide Copper-gold and Related Deposits: A Global Perspective. V. 1, Australian Mineral Foundation Inc, Adelaide.

Beane, R. E., \& Titley, S. R. (1981). Porphyry copper deposits: Part II. Hydrothermal alteration and mineralization. Economic Geology. 75th Anniversary . 15, 235-269.

Bedini, E. (2011). Mineral mapping in the Kap Simpson complex, central East Greenland, using HyMap and ASTER remote sensing data. Advances in Space Research, 47, 60-73.

Bi, X., Cornell, D. H., \& Hu, R. (2002). REE composition of primary and altered feldspar from the mineralized alteration zone of alkaline intrusive rocks, western Yunnan province, China. Ore Geology Reviews, 19, 6978.

Camprubí, A., González-Partida, E., López-Martínez, M., Iriondo, A., Alfonso, P., Cienfuegos-Alvarado, E., Gutiérrez-Armendáriz, E., Morales-Puente, P., Canet, C., \& González-Ruiz, L. (2016). The Upper Cretaceous Guaynopa IOCG and Guaynopita porphyry copper deposits, Chihuahua, Mexico. Ore Geology Reviewsm, 81, Part 3, 1096-1112.

Canny, J.F. (1987). A computational approach to edge detection, Readings in computer vision: issues, problems, principles, and paradigms. 184-203p.

Chang, D., Ren, H., D’Amico, F.M., \& Jensen, J. (2004). New Hyperspectral Discrimination Measure for Spectral Characterization, Optical Engineering, 43, 1777-1786.

Fakhari, S., jafarirad, A., Afzal, P., \& Lotfi, M. (2019) Delineation of hydrothermal alteration zones for porphyry systems utilizing ASTER data in Jebal-Barez area, SE Iran, Iranian Journal of Earth Sciences, 11(1) pp 8092. 
Grigoryev, N.A., Sazonov, V.N., \& Murzin, V.V. (1990). Sulfides as gold carriers in Skarn magnetite deposit Skarns and ores. Geochemistry International, 27, 142-146.

Guilbert, J. M., \& Park Jr, C. F. (2007). The geology of ore deposits. Waveland Press.

Henderson, P., (1989). Rare earth element geochemistry. Elsevier. 510 p.

Kesler, S. E., Jones, H. D., Furman, F. C., Sassen, R., Anderson, W. H., \& Kyle, J. R. (1994). Role of crude oil in the genesis of Mississippi Valley-type deposits: Evidence from the Cincinnati arch. Geology, 22, 609-612.

Khodami, M., \& Kamali Shervedani, A. (2018) Mineralogical and geochemical characteristics of the Chah-Shur clay deposit, Southeast of Isfahan, Iran, Iranian Journal of Earth Sciences, 10(2) pp 135-141.

Lottermoser, B. G. (1992). Rare earth elements and hydrothermal ore formation, Ore Geology Reviews, 7, 25-41.

Meinert, L. D. (1992). Skarns and Skarn deposits. Geoscience Canada, 19,145- 162.

Meinert, L. D., Dipple, G. M., \& Nicolescu, S. (2005).World skarn deposits. Economic Geology 100th Anniversary Volume, 299-336.

Najafzadeh, A., Khalili Mobarhan, Sh., \& Ahmadian, J. (2011). Economic Geology, Payam Nour University, Tehran, Iran, 409p, (Persian).

Nazemi, E., Arian, M.A., Jafarian, A., Pourkermani, M., \& Yazdi, A. (2019). Studying The Genesis Of Igneous Rocks In Zarin-Kamar Region (Shahrood, Northeastern Iran) By Rare Earth Elements. Revista Gênero e Direito, 8(4), 446-466. DOI: https://doi.org/10.22478/ufpb.2179-7137.2019v8n4.48442

Neal, L. C., Wilkinson, J. J., Mason, P. J., \& Chang, Z. (2018). Spectral characteristics of propylitic alteration minerals as a vectoring tool for porphyry copper deposits. Journal of Geochemical Exploration, 184, 179198.

Noori, L., Pour, A. B., Askari, G., Taghipour, N., Pradhan, B., Lee, C. W., \& Honarmand, M. (2019). Comparison of Different Algorithms to Map Hydrothermal Alteration Zones Using ASTER Remote Sensing Data for Polymetallic Vein-Type Ore Exploration: Toroud-Chahshirin Magmatic Belt (TCMB), North Iran. Remote Sensing, 11, $495 \mathrm{p}$.

Pearce, J. A., Harris, N. B., \& Tindle, A. G. (1984). Trace element discrimination diagrams for the tectonic interpretation of granitic rocks. Journal of petrology, 25, 956-983.

Pirajno, F. (2009). Hydrothermal processes and mineral systems. Springer Science and Business Media.1250p.

Pirajno, F., Hawke, P., Glikson, A. Y., Haines, P. W., \& Uysal, T. (2003). Shoemaker impact structure, Western Australia. Australian Journal of Earth Sciences, 50, 775-796.

Rokhbar, M., Sharifi, M., \& Qishlaqi, A. (2015). Concentration Survey of Lead, Zinc, Cadmiom, Selenium in Natural Herbs around the Lead and zinc Mine of Amrood Valley Ghohrood, South Kashan. 33rd National Geosciences Symposium, Tehran, Iran, (Persian).

Rollinson, H.R. (1993). Using geochemical data: evolution presentation, interpretation. London, UK. 652 P.

Rose, A. W., \& Burt, D. M. (1979). Hydrothermal alteration, In: Barnes, H. L. (Ed)., Geochemistry of Hydrothermal Ore Deposits, John Wiley and Sons, New York, 173 - 227p.

Winter, O. (2001). An introduction of igneous and metamorphic petrology. Department of Geology Whitman College. 697 p.

Yazdi, A., Ashja Ardalan, A., Emami, M. H., Dabiri, R., \& Foudazi, M. (2019) Magmatic interactions as recorded in plagioclase phenocrysts of quaternary volcanics in SE Bam (SE Iran), Iranian Journal of Earth Sciences, 11(3) pp 215-225.

Zadmehr, F., \& Shahrokhi, S. V. (2019) Separation of geochemical anomalies by concentration-area and concentration-number methods in the Saqez 1:100,000 sheet, Kurdistan, Iranian Journal of Earth Sciences, 11(3) pp 196-204. 